\title{
HARMONISASI SAINS DAN AGAMA: PENGEMBANGAN MODUL BIOLOGI BERBASIS INTERKONEKSI SAINS DAN NILAI-NILAI AGAMA
}

\author{
Idham Kholid ${ }^{1}$ \\ Supriyadi $^{2}$ \\ ${ }^{1,2)}$ Universitas Islam Negeri Raden Intan Lampung \\ E-mail: ${ }^{1}$ idhamkholid@ radenintan.ac.id, ${ }^{2}$ supriadi@ radenintan.ac.id
}

\begin{abstract}
Study on integration and interconnection of science and religion in education has been developed for quite a long time. However, most science teachers, especially biology teachers, do not understand enough how to integrate science and religion in biology learning. This research aims to develop a biology learning module based on the interconnection of science and religion in the model of guided inquiry learning. Developing this model is urgent to develop meta-cognitive knowledge and skill of prospective teachers in biology learning based on the interconnection of science and religion. This research uses the research and development methods (R\&D) with 4D steps: Define, Design, Develop, Disseminate. Data is gathered from expert validation, small group experiment, and the response of the experimental subject. The result shows that this module is very good at the following aspects: construction (score 94,5\%), didactic (score 94\%), technic (score 95\%), religion (score 92\%), and language (score $87 \%)$. In addition, students $(N=35)$ stated that this module is very interesting (score 95\%). They also aid that this module is easily used (score 90,22\%, efficient (score 92,85\%), and very clear (score 88,14). In conclusion, this developed learning module based on the interconnection of science and religion is adequate to implement for biology learning. This module also contributes to education institutions by presenting alternative references on the inter-discipline approach.
\end{abstract}

Kata kunci:: harmonisasi sains dan agama, pengembangan, modul biologi

\section{PENDAHULUAN}

Selama tiga dekade terakhir, wilayah agama dan sains telah mengalami evolusi secara dramatis. Evolusi tersebut dapat dimaknai sebagai kemajuan-disebabkan ekskalasi pengetahuan, pergeseran cara pandang, serta pasang surut hubungan keduanya. Hal itu menjadi tantangan baru bagi para peneliti untuk merevisi asumsi sebelumnya bahwa sains dan agama seringkali berinteraksi dalam retorika konflik.

Saat ini hubungan sains dan agama sedang dibangun dalam kerangka integrasiinterkoneksi. Banyak ahli berpandangan bahwa sains dan agama harus hidup berdampingan secara harmonis, karena keduanya merupakan dua kekuatan besar yang mempengaruhi kehidupan manusia. Maka sains dan agama tidak boleh terusmenerus berada dalam ketegangan yang tidak perlu (Stenmark, 2010; Riordan,
2019). Keduanya harus berpadu demi menghadapi tantangan kehidupan yang makin kompleks dan problematis.

Ide menyelaraskan hubungan sains dan agama sejatinya telah berkembang sejak lama. Sejumlah penelitian terkait rekonsiliasi hubungan sains dan agama pun sudah banyak dilakukan. Ian Barbour (1987; 2000; 2002; 2005), misalnya, cenderung menyarankan pandangan integrasi dalam membangun hubungan antara sains dan agama. Senada dengan hal itu, Haught (2012) menawarkan eksplorasi mendalam atas dimensi-dimensi sains dan agama, dan kemudian mencari keselarasan antara satu dengan yang lain. Sebelumnya, Capra, dkk. (1991) telah mengungkap pergeseran paradigma dalam ilmu pengetahuan dan teologi yang kemudian menciptakan ruang untuk menyatunya sains dan agama. Guiderdoni (2004), dari kalangan pemikir Islam, juga menerangkan 
bahwa agama dan sains dapat dipadukan. Menurut Guiderdoni ajaran utama Islam berprinsip bahwa semua jenis pendekatan terhadap realitas dunia pada akhirnya bisa dipadukan dan makna puncaknya diperoleh dalam perenungan terhadap wajah Tuhan di akhirat kelak.

Dalam etalase akademik yang lebih luas-melalui berbagai pandangan variatif namun bermakna sama-para pemikir yang turut memperjuangkan perdamaian sains dan agama dalam konteks isu-isu kontemporer juga cukup banyak. Sejumlah nama seperti Syed M. Naquib Al-Attas, Seyyed Hossein Nasr, Ismail Al-Faruqi, Ziauddin Sardar, Mehdi Gholsani, Nidhal Goessoum, Kuntowijoyo, Amin Abdullah, Audrey R. Chapman, dkk., Ahmedi Mahzar, Naseer Mansour, dll. akrab didengar.

Dalam konteks pendidikan, upaya untuk merekatkan hubungan sains dan agama dimulai dari pertanyaan penting: "Bagaimana pendidik bisa memberikan pembelajaran yang melampaui pandangan konflik antara sains dan agama? Bagaimana mengembangkan pendekatan yang reliabel dan konstruktif untuk pembelajaran yang mengaitkan sains dan agama? (Billingsley, dkk.. 2019).

Serangkaian penelitian di bawah naungan LASAR (Learning abaout Science and Religion) project menawarkan banyak bahan pemikiran yang dapat membantu dalam mengembangkan penelitian tentang integrasi sains dan agama dalam pembelajaran . Selain itu, Sollereder (2019) menyatakan peserta didik perlu dilatih mengajukan pertanyaan tentang sains dan agama saat belajar agar dapat menjangkau banyak hal tentang disiplin ilmu sains dan agama, serta isu-isu yang berkaitan dengan kehidupan manusia. Maka pembelajaran saat ini hendaknya membawa misi multidan inter-disipliner supaya dapat mengembangkan keluwesan peserta didik dalam melihat segala fenomena dari berbagai sudut pandang. Sejalan dengan gagasan tersebut, McLeish (2019) merekomendasikan perlunya teleologi sains dalam pembelajaran. Ini supaya peserta didik bisa tumbuh kesadarannya terkait peran manusia dalam merusak alam secara tidak manusiawi.

Di level praktik, White (2019) menawarkankan Filosofi Riceour. Filsafat ini memberikan wawasan penting bahwa pembelajaran sains dan agama dapat dilakukan melalui penggunaan analogianalogi dan metafora yang tersedia di sistem alam, juga nilai-nilai yang telah dikonstruksi oleh masyarakat sebelumnya yang bisa memberikan pemahaman kepada peserta didik tentang keselarasan hubungan sains dan agama dari aspek espitemologi dan metodologi. Tawaran ini diperkuat Oron, dkk (2019) melalui pengembangan pandangan inter-prosesual pada diri peserta didik. Dengan pandangan ini peserta didik dapat menghayati dan menghargai hubungan sains dan agama sebagai unit yang saling terkait dan tak terpisahkan dalam hal konteks dan cara pemahaman.

Sejalan dengan itu, Reiss (2019) mengajukan strategi yang tak kalah menarik. Reiss melihat bahwa sains dan agama bisa dipadukan melalui pendekatan konstruktif, yaitu keduanya bisa saling mengisi kekosongan, terutama dalam hal nilai dan capaian. Penerapannya, peserta didik diberi pemahaman bahwa capaiancapaian di bidang agama saat ini tak lepas dari kontribusi sains dan teknologi yang semakin maju. Namun harus diingat pula, kemajuan sains yang luar biasa bisa lepas kendali bila tak dikontrol dengan nilai dan etika yang dapat digali dari wahyu Tuhan. Sebagai contoh, Billingsley, dkk. (2019) mendesain pembelajaran berupa aktivitas membandingkan robot yang sangat mirip dengan manusia dengan manusia sesungguhnya. Perbandingan difokuskan pada masalah seputar kepribadian. Hasilnya terjadi peningkatan wawasan epistemik tentang sains dan agama, dan mereka terdorong untuk mengevaluasi keyakinan melalui analisis kekuatan dan keterbatasan sains.

Di lain sisi, Saether (2019) menekankan supaya pembelajaran sains, 
selain harus selalu berbasis sains dan teori pendidikan, juga tidak mengabaikan topiktopik yang berkaitan dengan agama-tanpa terpaku pada cara pandang, ideologi, nilai dan keyakinan seseorang. Artinya, perbincangan tentang sains dan agama dalam hal ini dapat dikemas dengan dialog seputar isu-isu konstektual dalam kehidupan sehari-hari peserta didik. Oleh sebab itu, Cameron (2019) mendorong agar pendidik berupaya membuat "jembatan, alih-alih hambatan" yang menghubungkan sains dan agama. Caranya bisa dengan melatih peserta didik untuk berpikir terbuka dan terbiasa menghadapi perdebatan epistemologis antara sains dan agama.

Jembatan itu dapat dikonstruksi dengan material pokok berupa komunikasi antara sains dan agama (Mansour, 2019). Maka percakapan, perdebatan, dan pertentangan tentang sains dan agama seharusnya menjadi budaya dalam pembelajaran. Itu akan bermanfaat dalam meningkatkan pemahaman yang lebih dalam tentang kehidupan kita, alam semesta kita, dan Tuhan.

Terakhir, Yap (2019) mencontohkan pembelajaran terkait sains dan agama menggunakan isu-isu sosio-saintifik melalui media film sains fiksi. Hasilnya, peserta didik tertarik untuk terlibat aktif dalam aktivitas penemuan pengetahuan ilmiah dan pemahaman konsep. Pendekatan ini juga memungkinkan peserta didik untuk menyadari bahwa sains dan teknologi sebagai hasil akal budi manusia melibatkan nilai-nilai epsitemik, sosial, dan agama.

Peserta didik juga dilatih untuk berpikir terbuka, berpikir sistem, dan multiperspektif. Dan yang terpenting, kepekaan mereka diasah dalam memahami bias (ambiguitas), melakukan refleksi secara kritis, berdebat secara meyakinkan, dan berpikir secara etis tentang bagaiman manusia memahami sifat realitas.

Berdasarkan uraian tersebut, peneliti memandang pentingnya meramu gagasangagasan filosofis, teoritik, contoh praktis tentang interkoneksi sains dan agama tersebut dalam pembelajaran biologi. Ramuan tersebut akan bermanfaat sebagai salah satu pedoman praktis bagi pendidik, calon pendidik, atau institusi pendidikan untuk menerapkan pembelajaran berbasis interkoneksi sains dan agama, terutama dalam pembelajaran biologi.

Asumsi itu dialasi hasil studi pendahuluan, bahwa hingga saat ini praktik pembelajaran biologi di sekolah umumnya belum berupaya merekatkan hubungan antara sains dan agama. Peningkatan sikap spiritual sebagaimana dianjurkan dalam kurikulum terbaru kerapkali baru dimanifestaikan dalam bentuk ritus ritual kegamaan umum seperti berdo'a, bersyukur, dll., sementara pemanfaatan konten (isi materi) pelajaran untuk mengungkap nilai-nilai agama belum banyak dilakukan.

Di kalangan pendidik wacana tentang integresi dan interkoneksi sains dan agama sejauh ini baru diperbincangkan pada tataran epistemologis. Di samping itu, bahan ajar yang secara representatif menggambarkan hubungan sains dan agama dalam pembelajaran biologi, untuk tidak mengatakan tidak ada, masih tergolong langka. Sehingga, pendidik terkendala saat ingin membelajarkan materi-materi biologi dengan mengaitkannya dengan nilai-nilai agama. Maka masalah minimnya pedoman pembelajaran biologi berbasis integrasi sains dan agama dapat direduksi dengan pengembangan modul ini.

Dipilihnya model pembelajaran inkuiri terbimbing sebagai jalan untuk untuk mewujudkan pembelajaran berbasis interkoneksi sains dan agama ini karena model tersebut dinilai relevan dengan arah pembelajaran biologi dalam kurikulum 2013.

\section{METODE}

Penelitian ini menggunakan desain research and development ( $\mathrm{R} \& \mathrm{D})$ dengan tahap 4D: Define, Design, Develop, Disseminate (Borg dan Gall, 2003). Subjek penelitian terdiri dari: (1) ahli (pakar) 
bahasa, ahli agama, ahli materi, ahli pembelajaran, ahli asesmen, ahli media yang berperan sebagai validator; (2) 3 (tiga) orang dosen mitra sebagai team teaching; (3) 10 (sepuluh) orang mahasiswa sebagai subjek ujicoba skala terbatas; (4) 35 (tiga puluh lima) orang mahasiswa sebagai subjek uji coba skala luas.

Tahap-tahap pengembangan modul meliputi:

1. Define atau research and information collection, merupakan fase analisis kebutuhan dan pengumpulan data awal berupa studi literatur, analisis masalah dan studi lapangan.

2. Design atau planning, merupakan aktivitas merancang produk meliputi merumuskan tujuan penyusunan produk, pengguna produk dan deskripsi komponen-komponen produk.

3. Develop atau develop preliminary form of product, merupakan pengembangan produk awal (prototype).

4. Disseminate, meliputi empat langkah: preliminary field testing atau ujicoba lapangan awal, main product revision atau revisi hasil ujicoba, main field testing atau ujicoba lapangan utama serta operational product revision atau penyempurnaan produk hasil ujicoba lapangan.

Data-data penelitian yang dijaring berupa: (1) komentar (catatan) dari para ahli (validator) mengenai kekurangan dan kelebihan modul; (2) Keputusan kelayakan menurut validator; (3) komentar atau catatan dari subjek ujicoba skala terbatas; (4) catatan lapangan oleh peneliti ketika ujicoba skala terbatas; (5) respon dari subjek ujicoba skala luas.

Berdasarkan ragam data penelitian tersebut, maka instrumen penelitian ini terdiri dari berupa lembar validasi (format expert judgement), lembar skala kelayakan modul dari validator, lembar catatan lapangan, angket respon subjek ujicoba penelitian.

Analisis data penelitian dilakukan dengan empat langkah: (1) menganalisis catatan-catatan tertulis dari para validator lalu memanfaatkannya untuk perbaikan modul; (2) menghitung persentase skor dari rating scale yang diisi oleh validator; (3) menganalisis catatan lapangan oleh peneliti lalu menggunakannya untuk meningkatkan kualitas modul; (4) menghitung persentase skor respon subjek ujicoba. Untuk menginterpretasi persentase data penelitian, peneliti membandingkannya dengan kriteria berikut ini.

Tabel 1. Kriteria persentase penilaian

\begin{tabular}{|c|c|}
\hline Rentang & Kriteria \\
\hline $81 \%-100 \%$ & Sangat baik \\
\hline $61 \%-80 \%$ & Baik \\
\hline $41 \%-60 \%$ & Cukup \\
\hline $21 \%-40 \%$ & Buruk \\
\hline $0 \%-20 \%$ & Sangat Buruk \\
\hline
\end{tabular}

Sumber: Akdon \& Riduwan (2013)

\section{HASIL}

Penelitian ini menghasilkan produk berupa modul pembelajaran biologi berbasis interkoneksi sains dan agama. Modul ini khas karena berisi pedoman pembelajaran biologi yang mengaitkan konten pelajaran biologi dengan nila-nilai agama. Operasionalisasi pembelajaran dalam modul menggunakan sintaks pembelajaran inkuiri terbimbing.

Di dalam modul ini nilai-nilai agama diharmonisasikan dengan sains dengan cara mengungkap keunikan yang melekat pada materi pelajaran lalu memanfaatkannya sebagai amtsal, perumpamaan, analogi, metaforan untuk merenungkan ke-Esaan Tuhan.

Modul ini tercipta melalui beberapa tahap berikut ini

\section{Analisis Teori/Studi Literatur}

Tahap ini dilakukan untuk menemukan landasan filosofis dan teoritik sebagai landasan untuk mengembangkan modul. Di sini peneliti mengkaji kurikulum pembelajaran biologi di SMA/MA meliputi analisis Kompetensi Inti dan Kompetensi Dasar. Hasilnya diketahui bahwa dalam kurikulum 2013 ternyata terdapat ruang mengaitkan sains dan agama. Kompetensi Inti I menerangkan supaya pembelajaran 
biologi dapat meningkatkan sikap spiritual peserta didik. Artinya nila-nilai agama dapat diajarkan secara eksplisit maupun implisit dalam pembelajaran biologi.

Selain itu, paradigma pembelajaran biologi juga diarahkan berpusat pada peserta didik. Ini dapat dimaknai bahwa pembelajaran biologi seharusnya melibatkan peserta didik untuk aktif dalam aktivitas penyelidikan dan pemecahan masalah dengan melalui proses ilmiah. Sehingga model pembelajaran inkuiri terbimbing relevan dengan tuntutan tersebut. Sebab, pembelajaran inkuiri menurut Dostal (2015) pada dasarnya sangat erat kaitannya dengan pengembangan dan praktik meningkatkan keterampilan berpikir dan pemecahan masalah.

Terkait harmonisasi sains dan agama, peneliti menganalisis berbagai rujukan antara lain: 1) buku "Science and Religion in Education" Billingsley dkk. (2019); "Islam dan Sains Modern" Guessoum (2007); "Bumi yang Terdesak" Chapman, dkk. (2007); "Menyatu dengan Semesta" Capra (1991) dan buku lain yang relevan sebagai referensi penting.

Buku-buku yang dikaji tersebut secara umum sepakat untuk meredam pandangan konflik antara sains dan agaman, dan menawarkan berbagai pendekatan untuk merekonsiliasi sains dan agama demi kemaslahatan umat manusia.

Pengembangan modul ini juga merujuk buku "Manajemen Alam:Sumber Pendidikan Nilai" Suroso Adi Yudianto (2011) yang secara detil mengungkap nilainilai karakter yang bersumber dari materi pelajaran sains.

Langkah selanjutnya, peneliti menganalisis masalah-masalah yang ada di lapangam berkenaan dengan pembelajaran biologi, terutama yang berkaitan dengan interkoneksi sains dan agama dalam pembelajaran biologi. Kegiatan ini ditempuh melalui observasi, wawancara, dokumentasi pada jurusan pendidikan biologi UIN Raden Intan Lampung, calon pendidik biologi, dan dosen biologi. Hasilnya diketahui bahwa pemahaman calon pendidik biologi dalam mengembangkan pembelajaran biologi berbasis interkoneksi sains dan agama tergolong rendah. Para dosen juga merasa kurang percaya diri, karena menyadari keterbatasan pemahaman, untuk mempraktikkan pembelajaran yang mengaitkan sains dan agama di kelas-kelas mereka. Mereka mengatakan meskipun sudah sering mendengar dan mebicarakan wacana integrasi-interkoneksi keilmuan, tapi mereka merasa belum menguasai materi sains dan agama secara menyeluruh, terutama dalam hal bagaimana mengaitkan keduanya, dan bagaimana meramu hubungan itu dalam pembelajaran.

\section{Penyusunan Tema}

Langkah yang dilakukan setelah potensi dan masalah dirumuskan yakni mengumpulkan berbagai informasi sebagai bahan untuk merencanakan pembuatan produk. Pada tahap ini peneliti merumuskan pokok-pokok materi yang akan disajikan dalam modul. Akhirnya, modul ini dikemas dangan tajuk "Harmonisasi Sains dan Agama: Panduan Praktis untuk Pembelajaran Biologi".

\section{Desain Produk}

Tahap ini merupakan kegiatan peneliti menyusun rancangan modul. Langkah-langkahnya antara lain:

a. Pembuatan layout modul

Tahap ini peneliti menerapkan format-format modul, mendesain sampul, menyusun outline, dll. Kerangka tersebut menggambarkan keseluruhan modul baik bagian dalam maupun bagian luar. Setelah beberapa kali berdiskusi dan melakukan beberapa perubahan dihasilkan tampilan luar modul sebagaimana ditampilkan pada Gambar 1. 


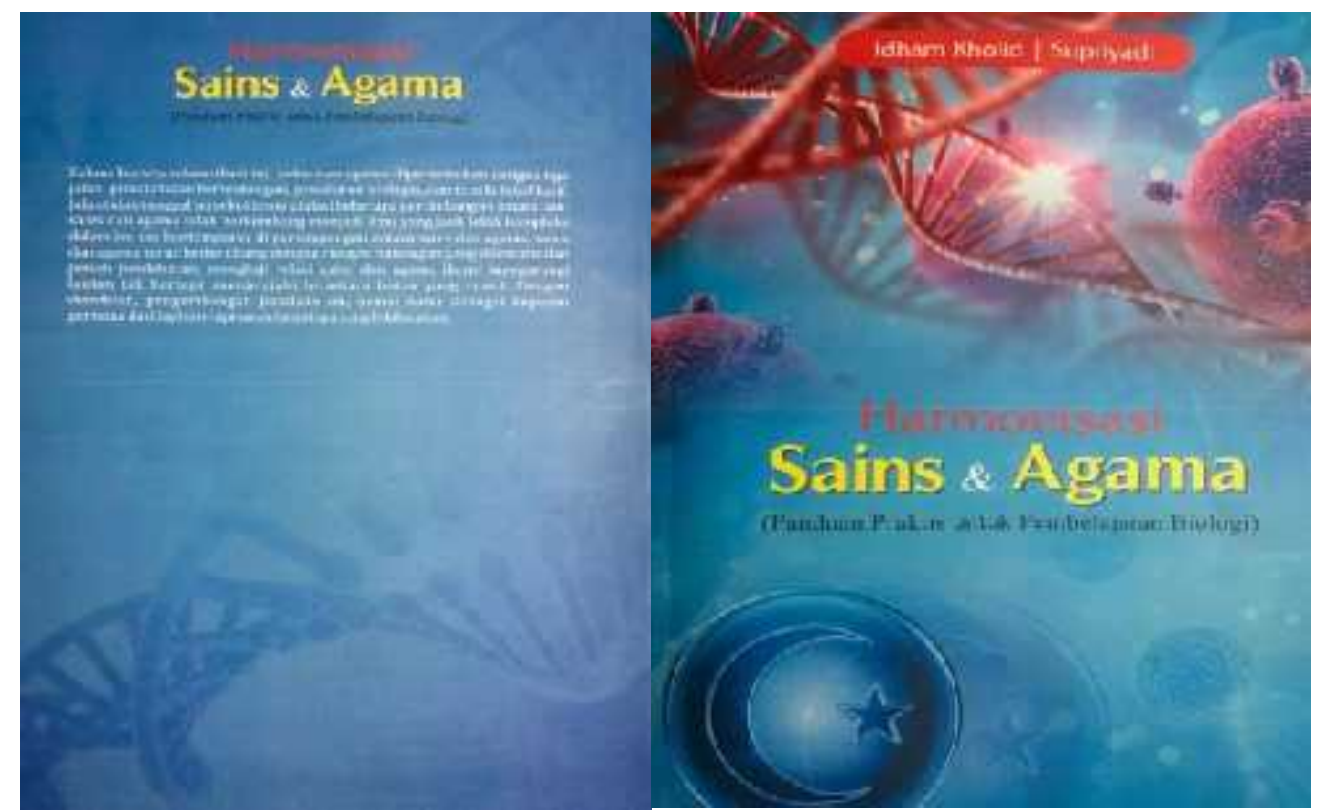

Gambar 1. Profil modul bagian luar

b. Penyusunan isi modul

Modul ini disusun sebanyak 11 (sebelas) bab. Bab I berisi pengantar tentang pentingnya interkoneksi sains dan agama dalam pembelajaran; Bab II-V memuat hal-hal seperti landasan teoritis hakikat sains dan agama, pembelajaran holistik, pemberdayaan kemampuan berpikir, tantangan pembelajaran sains abad 21, dan model pembelajaran ikuiri terbimbing; Bab VI-X memuat petunjuk pembelajaran dengan model inkuiri terbimbing berbasis interkoneksi sains dan agama pada konsep-konsep biologi seperti Virus, Ekosistem, Plantae, Evolusi, Sistem Eksresi; Bab XI berisi penutup.

Berdasarkan analisis Kompetensi, tujuan pembelajaran pada modul ini dirumuskan untuk membangun sikap spiritual, sikap sosial, kognitif, dan psikomotorik. Pengembangan sikap spiritual adalah jalan awal mengaitkan nilai-nilai agama (spiritualitas) dengan dimensi sains melalui materi pelajaran biologi. Manifestasi interkoneksi sains dan agama kemudian diwujudkan melalui pengembangan sikap sosial, kognitif, dan psikomotorik, karena sejatinya ajaran atau nilai-nilai agama juga menyangkut ranahranah itu.

Misalnya pada BAB IV tentang pembelajaran konsep Virus. Ketika belajar tentang Virus, peserta didik dilatih untuk mengungkap nilai religius, nilai intelektual, nilai sosial, dan nilai psikomotorik melalui aktivitas penyelidikan, diskusi, refleksi, dan pemecahan masalah. Pengembangan sikap spiritual dalam dilakukan dengan cara misalnya, mengembangkan sikap kagum karena menghayati keindahan, keteraturan dan kompleksitas ciptaan Tuhan yang melekat pada struktur tubuh, karakteristik, dan daur hidup Virus. Sebelumnya diterangkan terlebih dahulu bahwa Virus merupakan subtansi unik. Virus hadir di alam semesta sebagai objek kajian dengan karakteristik unik: benda mati sekaligus makhluk hidup.

Kerumitan karakteristik itu hingga saat ini belum dapat terpecahkan secara tuntas oleh para ahli. Itulah kekuasaan Tuhan yang menciptakan misteri (kotak hitam) dalam setiap ilmu pengetahuan supaya terus semangat untuk memberdayakan kemampuan berpikir dan daya jelajah untuk mempelajari alam semesta yang amat luas. Selain itu peserta didik juga dapat diasah kesadarannya terkait keterbatasan kemampuan manusia dalam memahami alam semesta sehingga tumbuh sifat mawas diri. Semua fenomena di alam semesta kemudian diinsyafi tak lepas dari kendali kekuasaan Tuhan Yang Maha Kuasa sebagaimana termaktub dalam 
AL-Qur' an, misalnya, Surah Ali-Imran ayat 26-27.

Nilai spiritual yang dapat dipetik melalui pembelajaran konsep Virus yaitu bahwa Virus yang kita pelajari atau dapat kita rasakan melalui penyakit yang disebabkan Virus sejatinya kedudukannya sama dengan manusia yaitu sama-sama ciptaan-Nya. Manusia dan Virus hanya berbeda dalam hal tugas fungsional di alam semesta. Oleh sebab itu, manusia harus taat kepada aturan dan keteraturan yang didesain Tuhan.

Terkait pengembangan sikap sosial, pembelajaran biologi dianjurkan untuk menghasilkan peserta didik yang berperilaku ilmiah: teliti, tekun, jujur terhadap data dan fakta, disiplin, tanggung jawab, dan peduli dalam observasi dan eksperimen berani dan santun dalam mengajukan pertanyaan dan berargumentasi, peduli lingkungan, gotong royong, bekerjasama, cinta damai, berpendapat secara ilmiah dan kritis, responsif dan proaktif dalam setiap tindakan dan dalam melakukan pengamatan dan percobaan di dalam maupun di luar kelas/laboratorium.

Sikap sosial dari konsep Virus dapat digali dengan dua cara. Pertama, menumbuhkan sikap ilmiah melalui kegiatan penyelidikan, misalnya melatih peserta didik untuk mampu (1) bersikap teliti saat mengamati stuktur tubuh, karakteristik, dan siklus hidup Virus; (2) bersikap santun saat mendiskusikan peran Virus dalam kehidupan; (3) bekerjasama dalam mengembangkan model atau charta struktur tubuh Virus. Perilaku ilmiah peserta didik yang dapat diamati ketika mereka (1) Menggambarkan struktur tubuh virus dengan detil; (2) Tidak menyela peserta didik lain yang sedang mengutarakan pendapat; (3) Tidak menggunakan kata-kata kasar saat berdiskusi; (4) Tidak menghina (bersikap rasis) ketika menyangkal pendapat peserta didik lain; (5) Turut andil menyiapkan alat dan bahan percobaan dan menyelesaikan tugas secara bersama-sama.
Kedua, melalui sintesis nilai-nilai sosial dari konsep Virus, misalnya, pengembangan sikap mandiri. Virus dikenali sebagai organisme parasit yang hanya dapat hidup bila ada inang karena tidak memiliki sumber daya untuk memproduksi kebutuhan hidupnya sendiri. Ketika virus berada dalam tubuh inang, ia bersifat merusak/menimbulkan penyakit. Fenomena itu mengajarkan bahwa sebagai manusia yang dibekali potensi akal budi kita harus senantiasa memupuk kemandirian dalam berbagai hal, seperti kemandirian belajar, kemandirian ekonomi, kemandirian dalam bekerja, dll. Kemandirian penting untuk meningkatkan kewibawaan, membuat kita tegar dalam bekerja, meneguhkan pendirian, dan menghindarkan kita dari peluang menjadi parasit. Sebab berprilaku seperti parasit, apalagi parasit sosial, ibarat menyemai bibit kanker di tubuh sendiri. Selain itu, masih banyak contoh lain yang dapat dielaborasi.

Pembelajaran konsep Virus juga diarahkan untuk memabngun pemahaman peserta didik tentang karakteristik Virus, serta manfaat dan bahaya Virus sehingga dapat diterapkan dalam kehidupan. Lewat pemahaman itu peserta didik bisa menerapkan pola hidup sehat, menjaga kebersihan lingkungan dan diri serta tidak melakukan perilaku menyimpang seksual agar terhindar dari penularan penyakit menular seksual.

Pemberdayaan keterampilan berpikir tingkat tinggi juga dapat dilakukan melalui aktivitas merumuskan pertanyan-pertanyan kritis dan berupaya menemukan solusinya, misalnya "Mengapa virus HIV/AIDS menyerang manusia, dan bukan anjing atau tumbuhan? Bagaimana agar Covid-19 dapat dicegah penyebarannya? Tindakan apa saja yang Anda lakukan untuk menyikapi wabah Covid-19 ini? Apakah wabah Covid-19 ada relasinya dengan keserakahan manusia dan atau kemarahan Tuhan? Pertanyaan-pertanyaan socratik tersebut merupakan pertanyaan kontekstual yang mendekatkan materi pembelajaran dengan keadaan nyata yang dialami peserta didik. 
Keterampilan atau psikomotorik dikembangkan melalui aktivitas menyajikan data (tabulasi data). Kemampuan ini penting sebagai ketrampilan dasar mengolah informasi supaya lebih mudah dipahami dan menarik untuk dibaca. Peserta didik yang dilatih keterampilan tabulasi data berpeluang berkarir dibidang infografis, pemetaan, pusat data satistik dan lain sebagainya.

Di samping itu, belajar Virus juga berguna untuk mengasah kreativitas untuk menciptakan karya seni yang terinspirasi dari struktur tubuh Virus yang indah, juga dampak Virus yang memberikan kesan misterius. Motif batik Virus Corona, motif batik Ketsa, merupakan contoh terbaik bagaimana penghayatan seseorang ketika mengamati dan menggambar struktur tubuh virus bisa mengakibatkan imajinasi dan kemudian melahirkan karya yang indah dan bernilai ekonomi.

\section{Validasi modul}

Validasi modul merupakan aktivitas mengkonsultasikan kelayakan modul kepada para ahli seperti telah dijelaskan dalam metode penelitian. Setelah menganalisis tanggapan dari para validator dalam lembar skala kelayakan modul, berikut ini disajikan ikhtisar hasil validasi modul.

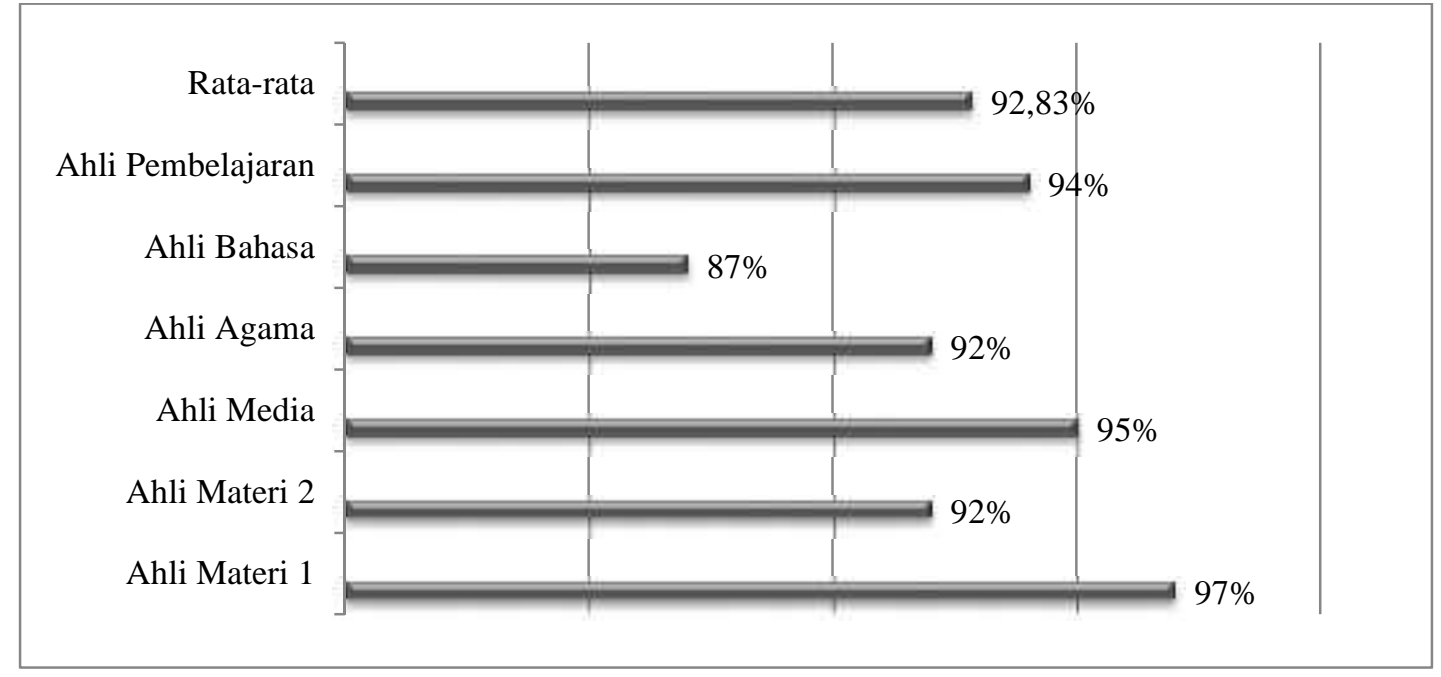

Gambar 2. Hasil validasi modul

Berdasarkan diagram di atas, modul yang dikembangkan termasuk dalam kriteria sangat baik menurut para ahli. Beberapa catatan penting dari ahli terkait kekurangan-kekurangan modul ini selanjutnya diperbaiki pada tahap revisi desain.

\section{Revisi Modul}

Pokok-pokok perbaikan dari para pakar digunakan untuk revisi modul. Setelah diperbaiki, modul diajukan kembali kepada para pakar dan telah disetujui. Revisi ahli materi meliputi kejelasan gambar dan penambahan jumlah referensi. Kedua catatan itu telah dipenuhi. Terkait kejelasan gambar, selain memperbesar ukuran gambar, memperjelas keterangan dan deskripsi, kami juga menambahkan gambar pembanding yang bersumber dari www_argosymedical_com;https://micro.ma gnet.fsu.edu/ sehingga gambar lebih detil dan jelas. Terkait tambahan sumber bacaan dan link pengayaan kami menambahkan website https://www.biologycorner.com/.

Revisi dari ahli pembelajaran diwujudkan dengan penambahan wacana sebagai ilustrasi pembuka pada sintaks orientasi masalah.

Ahli media menghendaki perubahan warna sampul, kesesuaian ilustrasi dengan tema, dan posisi judul. Hal itu dipenuhi dengan mengubah warna sampul dari sebelumnya dominan hitam menjadi biru. Ilustrasi sampul yang sebelumnya berupa galaksi dan alam semesta kini dilengkapi dengan unsur-unsur yang berkaitan materi 
biologi berupa rantai DNA dan Virus. Posisi judul yang sebelumnya di bagian atas digeser ke tengah dan diubah warna font-nya.

Revisi ahli bahasa berupa pemilihan diksi yang kurang tepat, penggunaan tanda baca yang tidak pada tempatnya, kesalahan pengetikan perlu diperbaiki. Dari aspek konten, penyampaian gagasan, kohesi dan koherensi antar kalimat dan paragraf yang harus ditinjau kembali telah dipenuhi dengan membaca kembali modul dan memperbaikinya pada bagian-bagian sesuai catatan validator.

Revisi ahli agama dilakukan dengan menghapus kutipan ayat menggunakan bahasa Arab, diganti dengan pengutipan menggunakan bahasa Indonesia unutk menghindari kesulitan-kesulitan pembacaan dan pemahaman. Berkenaan dengan tafsir, peneliti menambahkan tafsir pada beberapa ayat yag dikutip untuk memudahkan pemaknaan terhadap ayat-ayat yang dipilih tersebut. Dengan demikian, upaya untuk mempertemukan suatu ayat dengan materi semakin mudah dan relevan.

\section{Ujicoba Produk}

Uji kelayakan produk dilakukan dengan ujicoba skala terbatas dan ujicoba skala laus. Pada ujicoba skala terbatas, peneliti memilih sebanyak 10 (sepuluh) subjek ujicoba dengan teknik satu lawan satu. Para subjek ujicoba diberikan kesempatan selama satu minggu untuk mencoba membaca dan memahami isi modul, kemudian memberi catatan kekurangan-kekurangan modul.

Pada minggu kedua mereka diminta untuk mencoba mengerjakan modul tersebut. Catatan lapangan mengenai kekurangan-kekurangan atau kesulitan subjek ujicoba saat mengerjakan modul menjadi bahan untuk perbaikan. Hasil ujicoba modul skala terbatas diketahui secara umum modul dapat digunakan dengan sangat baik. Selama mempelajari dan menggunakan modul tersebut para subjek ujicoba tidak menemui kendala yang berarti. Adapun masalah-masalah yang ditemui hanya klarifikasi seputar langkahlangkah apa saja yang harus dilakukan subjek ujicoba untuk memahami modul ini.

Langkah selanjutnya, kami melakukan ujicoba produk skala luas. Sebanyak 35 (tiga puluh lima) subjek ujicoba dipilih sebagai partisipan. Mereka diberi waktu selama 3 (tiga) minggu untuk membaca, mempelajari, dan menggunakan modul tersebut. Langkah berikutnya peneliti memberikan angket respon kepada peserta didik. Hasil analisis respon subjek ujicoba ditampilkan pada Gambar 3. di bawah ini.

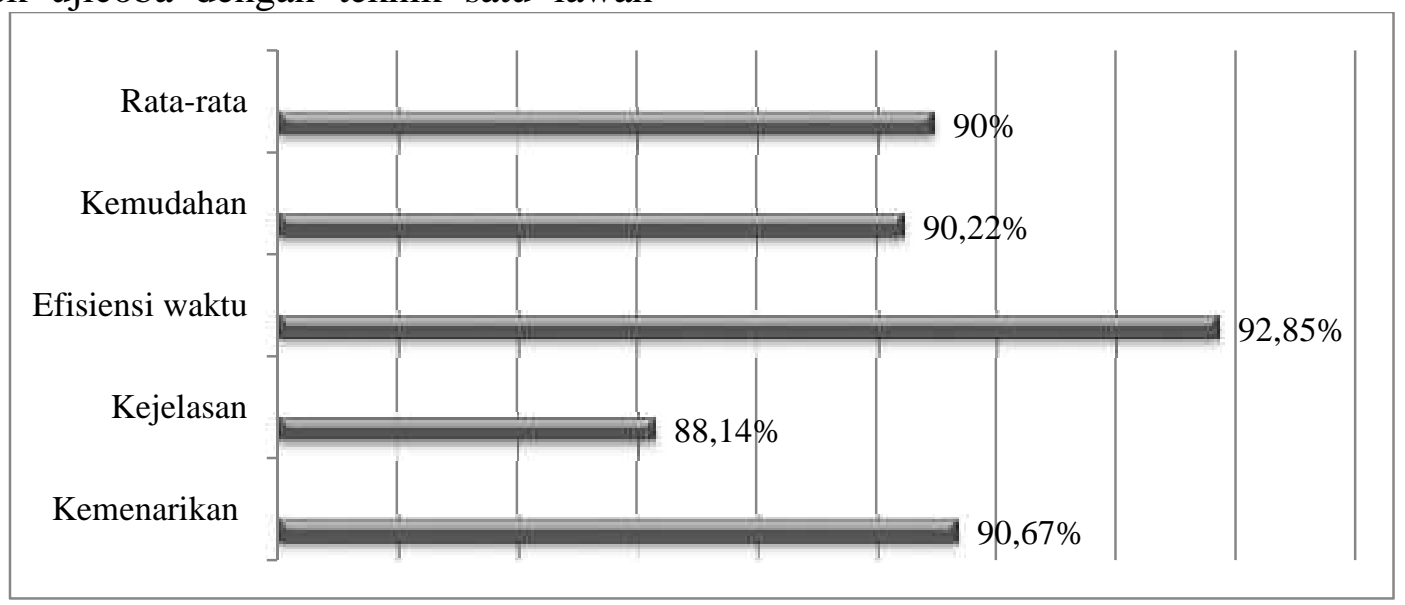

Gambar 3. Hasil respon subjek ujicoba

Sesuai dengan diagram tersebut, dapat diketahui bahwa secara umum modul yang dikembangkan mendapat respon positif dari subjek ujicoba dengan kriteria sangat baik.
Artinya, modul ini sangat mudah digunakan.

\section{Penyempurnaan Produk}


Setelah merekap seluruh catatan dari validator, hasil catatan lapangan, dan respon dari subjek ujicoba, peneliti memeriksa kembali (mengevaluasi) desain modul. Alhasil, semua masukan dan catatan tersebut digunakan untuk meningkatkan kualitas modul agar mendekati sempurna.

\section{PEMBAHASAN}

Modul pembelajaran biologi berbasis interkoneksi sains dan agama telah selesai dikembangkan. Sebagaimana diuraikan sebelumnya, pengembangan ini menggunakan metode research and development (Borg and Gall, 2003). Karakter yang kuat dari modul ini adalah pengembangan pada aspek interkoneksi sains dan nilai-nilai agama dalam pembelajaran biologi melalui model pembelajaran inkuiri terbimbing. Hal ini mengindikasikan bahwa modul dikembangkan dengan mengacu pada gagasan pembelajaran interdisipliner (Abdullah, 2007). Konsep interkoneksi dibangun atas dasar perubahan paradigma dalam ilmu pengetahuan dan pemikiran paradigma baru dalam teologi (Capra, 1991) yang memberi ruang dan sekaligus jalan untuk bertemunya sains dan agama. Pergeseran pada masing-masing tersebut dimulai tersebut digambarkan antara lain: pada wilayah sains, perubahan-perubahan itu meliputi (1) Paradigma Ilmiah lama, atau sering disebut Cartesian, Newtonian, Baconian, yang memiliki ciri khas parsial dan segmented bergeser ke paradigma holistik, ekologis, dan sistemik; (2) Pergeseran cara pandang manusia atas alam; (3) Pergeseran struktur ke proses; (4) Pergeseran ilmu pengetahuan objektif menjadi epistemik; (5) Pergeseran metafora pengetahuan dari Bangunan menjadi Jaringan; (6) Pergeseran dari kebenaran mutlak (objektif) menuju kebenaran relatif (deskriptif).

Pada wilayah agama, pergeseran yang dimaksud meliputi (1) pergeseran paradigma teologi lama yang disebut paradigma rasionalistik, manualistik atau Skolastik-Positivistik menuju paradigma holistik, ekumenis atau ThomistikTransendental; (2) Pergeseran dari Tuhan sebagai Pemberi Kebenaran menjadi Realitas sebagai Penyingkap diri Tuhan; (3) Pergeseran cara pandang terhadap wahyu Ilahi; (4) Pergeseran dari Wahyu sebagai Kebenaran Abadi kepada Wahyu sebagai Manifestasi Historis; (5) Pergeseran dari Teologi sebagai Ilmu Objektif kepada Teologi sebagai Proses Mengetahui; (6) Pergeseran Fokus dari PernyataanPernyataan Teologis kepada MisteriMisteri Ilahi.

Sintesis dari perubahan-perubahan itu adalah lahirnya paradigma keilmuan sains dan agama yang lebih terbuka, saling sapa, dan saling isi. Di titik inilah, modul ini mendapat pijakannya saat melatih peserta didik untuk membiasakan berpikir holistiksistemik terhadap materi pelajaran yang dikaji.

Perbincangan sains dan agama sebagaimana diungkap dalam modul ini dirancang melampaui batas-batas keyakinan individu seseorang yang memang telah memiliki modal keyakinan agama yang beragam. Sekat-sekat perbedaan ini diruntuhkan lewat pengungkapan isu-isu kontemporer (lingkungan, sosial) sebagai titik temu, atau dalam istilah Cemaron (2019); sebagai jembatan, yang menghubungkan antara sains dan agama (Chapman, dkk., 2007; Guessoum, 2014). Kemudian, dalam modul ini permasalahan-permasalahan mutakhir tersebut dimanfaatkan untuk menumbuhkan sikap spritual, sikap sosial, konitif, dan psikomotorik, sebagai manifestasi penanaman nilai agama. Lewat jalan ini, peserta didik dapat melatih diri untuk menghargai masing-masing wilayah sains dan agama (Oron, dkk., 2019).

Secara operasional modul ini berupaya mengungkap keunikan materi pelajaran biologi kemudian menggunakannya sebagai analogi (amtsal) untuk memabngun berbagai kesadaran peserta didik. Hal ini terinspirasi dari gagasan Suroso Adi Yudianto (2011) yang sebelumnya telah mengembangkan karakter 
unggul peserta didik lewat sintesis nilainilai yang melekat pada materi pelajaran biologi (sains). Upaya serupa juga telah digagas oleh Nathan H. White (2019) lewat Filosofi Riceour-nya. Pengembangan modul yang sesuai dengan nilai-nilai Islam juga salah satunya adalah dapat menyediakan sarana dan prasarana pendukung untuk terciptanya peserta didik yang unggul dalam prestasi serta religius Larasati, Dkk (2020).

Maka modul ini dinilai memiliki keunggulan-keunggalan antara lain: (1) praktis; (2) relevan dengan gagasan pembelajaran interdisipliner; (3) dapat digunakan untuk mengembangkan empat pilar kompetensi peserta didik; (4) relevan dengan arah pembelajaran biologi. Namun, beberapa kelemahan juga mungkin ditemui dalam modul ini, misalnya, (1) sumbersumber yang digunakan untuk mengkonfirmasi nilai agama baru berpusat pada Wahyu agama Islam; (2) materi biologi yang dipilih baru beberapa konsep, belum mencakup semua materi biologi.'

Pada akhirnya, modul pembelajaran ini diharapkan dapat menjadi pedoman praktis untuk pembelajaran biologi dalam rangka melatih peserta didik untuk terbiasa memperbincangkan sains dan agama. Sebab secara kualitas modul ini, menurut para validator validator dan hasil ujicoba, sangat layak, kendati tetap diperlukan penyempurnaan terus menerus. Dengan demikian, sebagaimana saran dari (Cheetham, 2019), peserta didik atau elemen-elemen pendidikan dapat terlatih membangun komunikasi yang harmonis antara sains dan agama.

\section{KESIMPULAN}

1. Proses pengembangan model inkuiri terbimbing berbasis interkoneksi sains dan agama berdasar pada metode research and development (R\&D) meliputi tahap Define, Design, Develop, and Disseminate.

2. Hasil validasi ahli materi, ahli pembelajaran, ahli agama, ahli bahasa, ahli media, diketahui model yang dikembangkan ini tergolong sangat baik.

3. Subjek ujicoba modul memberikan respon positif (sangat baik) terhadap kehadiran modul ini dengan kriteria sangat menarik, jelas, sangat bermanfaat, dan sangat mudah digunakan.

\section{SARAN}

Kajian seputar integrasi-interkoneksi sains dan agama, selain kompleks, juga merupakan wilayah kajian yang sangat luas. Ibarat lapisan bawang, penelitian ini barangkali baru lapisan pertama dari lapisan-lapisan yang lebih dalam. Oleh sebab itu, tentu masih banyak ruang untuk penelitian lanjutan tentang topik menarik ini. Beberapa hal yang dapat kami rekomendasikan antara lain.

1. Perlu adanya elaborasi model-model pembelajaran lain yang diuji coba.

2. Wilayah agama bisa diperluas pada konteks agama lain selain islam.

\section{DAFTAR RUJUKAN}

Abdullah, M.A. 2007. Desain Pengembangan Akademik IAIN menuju UIN Sunan Kalijaga: Dari Pendekatan Dikotomis-Atomistis ke arah Integratif-Interkonektif, dalam Fahrudin Faiz (Eds.) Islamic Studies dalam Paradigma IntegrasiInterkoneksi. Yogyakarta: SUKA Press.

Adi Yudianto, Suroso. 2005. Manajemen Alam: Sumber Pendidikan Nilai. Bandung. Mugni Sejahtera.

Akdon dan Riduwan. 2013. Rumus dan Data dalam Aplikasi Statistika. Bandung: Alfabeta

Al-Qur' an Terjemahan. 2015. Departemen Agama RI. Bandung: CV Darus Sunnah.

Barbour, I. 1987. Religion and Science: Historical and Contemporary issues, rev.ed. San Fracisco. HarperCollins.

Barbour, I. 2000. When sciences meets religion. San Fracisco. HarperCollins.

Barbour, I. 2002. Juru Bicara Tuhan: 
Antara Sains dan Agama, terj. E.R. Muhammad. Bandung: Penerbitan Mizan.

Borg and Gall. 2003. Educational Research. New York: Allyn and Bacon.

Barbour, I. 2005. Manusia, Alam, dan Tuhan: Menyepadukan Sains dan Agama. Pengantar Armahedi Mahzar. Bandung: Penerbitan Mizan.

Billingsley, B., Riga, F., Taber, K. S., \& Newdick, H. 2014. Secondary School Students' Epistemic Insight into the Relationships between Science and Religion-A Preliminary Enquiry. Research in Science Education, 43 (4), 1715-1732.

Billingsley, B., Nassaji, M., Fraser, S., \&, F. 2018. A Framework for Epistemic Insight. Research in Science Education, 48(6), 1115-1131. https://doi.org/1007/s11165-0189788-6.

Billingsley, B., Chappell, K., Reiss, M. (Eds). 2019. Science and Religion in Education: Contemporary Trends and Issues in Education 48. Switzerland: Springer Nature Switzerland AG.

Billingsley, K. and Nassaji, M. 2019. Develoing a Workshop for Secondary School Students that Provides a Space to Explore Questions about Human Personhood through the Context of Human-like Machines (hlm 141-152). In Billingsley dkk. (Eds.), Science and Religion in Education: Contemporary Trends and Issues in Education 48. Switzerland: Springer Nature Switzerland AG.

Cameron, A. 2019. Cultural and Religious Barriers to Learning Sciences in Shouth Africa (hlm 189-202). In Billingsley dkk. (Eds.), Science and Religion in Education: Contemporary Trends and Issues in Education 48. Switzerland: Springer Nature Switzerland AG.

Capra, F., Steindl-Rast, D., Matus, T. 1991.
Menyatu dengan Semesta:

Menyingkap Batas antara Sains dan Spiritualitas. Yogyakarta: Fajar Baru Pustaka

Chapman, A.R., Petersen, L., and SmithMoran, B. 2007. Bumi yang Terdesak: Perspektif Ilmu dan Agama mengenai Konsumsi, Populasi, dan Keberlanjutan. Bandung: PT Mizan Pustaka bekerjasama dengan CRCS UGM.

Cheetham, R. 2019. Lies, Damned Lies, Science, and Theology: Why Everyone Needs to Know the Truth about Science and Religion (hlm 227238). In Billingsley dkk. (Eds.), Science and Religion in Education: Contemporary Trends and Issues in Education 48. Switzerland: Springer Nature Switzerland AG.

Dostal, J. 2015. Theory of Problem Solving. Procedia Social and Behaviorial Sciences. 174:27982805.

Gholsani, M. 2004. Melacak Jejak Tuhan dalam Sains: Tafsir Islami atas Sains. Bandung: Penerbitan Mizan.

Guessoum, N. 2011. Islam dan Sains Modern: Bagaimana mempertemukan Islam dan Sains Modern. Bandung: Mizan Media Utama.

Guessoum, N. 2018. Science and Relegion Issue In Higher Education. Https://www.researchgate.net/publica tion/32457974.DOI:10.1007/978-3319-73111-7-10.

Guidardoni, B. 2004. Membaca Alam, Membaca Ayat, terj. Anton Kurnia dan Andar Nubowo. Bandung: Mizan Pustaka..

Haught, J.F. 2012. Science and Faith: A New Introduction. New York. Paulist Press.

Larasati, A. D., Lepiyanto, A., Sutanto, A., \& Asih, T. (2020). Pengembangan emodul terintegrasi nilai-nilai islam pada materi sistem respirasi. Didektika Biologi:Jurnal Penelitian Pendidikan Biologi, 4(1), 1-9.

LASAR (Learning about Science and 
Religion) project. 2016. Science and religion in education conference 2016.http://lasarcentre.com/scienceand-religion-in educationconference_2016/.Diakses 16 Mei 2019

Mansour, N. 2019. Science, Religion, and Pedagogy: Teachers' Prespectives (hlm 315-336). ). In Billingsley dkk. (Eds.), Science and Religion in Education: Contemporary Trends and Issues in Education 48. Switzerland: Springer Nature Switzerland AG.

McLeish, T.C.B. 2019. Beyond Barbour: A Theology of Science from Ancient and Modern Thinkers. In Billingsley dkk. (Eds.), Science and Religion in Education: Contemporary Trends and Issues in Education 48. Switzerland: Springer Nature Switzerland AG.

Oron, J.F., Akrivou, K., and Scalzo, G. 2019. Autonomous Self and InterProcessual Self: Two Ways of Explaining How People "See" and Live Relationships and the Resulting Dialogue between Science and Faith (91-102). In Billingsley dkk. (Eds.), Science and Religion in Education: Contemporary Trends and Issues in Education 48. Switzerland: Springer Nature Switzerland AG.

Reiss, M.J. 2019. Beyond Bare Statistics (hlm 119-122). In Billingsley dkk. (Eds.), Science and Religion in Education: Contemporary Trends and Issues in Education 48. Switzerland: Springer Nature Switzerland AG.

Riordan, S. 2019. The Moral Impact of Studying Science. In Billingsley dkk. (Ed.), Science and Religion in Education: Contemporary Trends and Issues in Education 48. Switzerland: Springer Nature Switzerland AG.

Saehter, J. 2019. Three Prepective on the Science-Religion Issue in Science Education: Interdisciplinarity, Value, or Ideology Orientation and Resposible Personalization (hlm 153168). In Billingsley dkk. (Eds.), Science and Religion in Education: Contemporary Trends and Issues in Education 48. Switzerland: Springer Nature Switzerland AG.

Stenmark, M. 2010. Ways to relating science and religion. In P. Harison (Eds.), The Cambrigde companion to science and religion. Cambridge: Cambridge University Press.

Sollereder, B. 2019. Beyond Barbour: New Ways of Teaching the Relationship between Science and Religion. In Billingsley dkk. (Eds.), Science and Religion in Education: Contemporary Trends and Issues in Education 48. Switzerland: Springer Nature Switzerland AG.

White, N.H. 2019. The Mediated Nature of Knowledge: Paul Riceour's Philosophy as a Means of Teaching Students abaout Science and Religion (hlm 63-76). In Billingsley dkk. (Eds.), Science and Religion in Education: Contemporary Trends and Issues in Education 48. Switzerland: Springer Nature Switzerland AG.

Yap, S.F. 2019. Interface between science and faith values in movies with a focus on the use of socio-scientific issues (SSI) in an Australian Cristian College (hlm 239-258). In Billingsley dkk. (Eds.), Science and Religion in Education: Contemporary Trends and Issues in Education 48. Switzerland: Springer Nature Switzerland AG. 